\title{
Social representations of the Coronavirus and causal perception of its origin. The role of reasons for fear.
}

\author{
Patrick Rateau ${ }^{1}$ \\ Jean Louis Tavani ${ }^{2}$ \\ Sylvain Delouvée 3
}

1. Laboratoire CHROME (EA 7352) - Université de Nîmes, France. ORCID iD: 0000-00016340-4676.

2. Laboratoire Parisien de Psychologie Sociale (EA 4368) - Groupe de Recherche sur la Parole et la Pensée Sociale - Université Paris 8 - Vincennes-Saint-Denis. 93200 Saint Denis, France. ORCID iD: 0000-0003-2736-4595.

3. Univ Rennes, LP3C (Laboratoire de Psychologie: Cognition, Comportement, Communication) - EA 1285, F-35000 Rennes, France. ORCID iD: 0000-0002-4029-597X.

Correspondence concerning this article should be addressed to: Patrick Rateau, Université de

Nîmes. Rue du Docteur Georges Salan, CS 13019, 30021 Nîmes Cedex 1, France,

+33(0)630053933, patrick.rateau@unimes.fr

Declarations of interest : none. 


\title{
Social representations of the Coronavirus and causal perception of its origin. The role of reasons for fear.
}

\begin{abstract}
In the midst of the Covid-19 pandemic (between 26 March and 2 April 2020), we analysed $(n=1144)$ the social representations of the coronavirus and the differentiated perceptions according to the origins attributed to the appearance of the virus (Human vs Non-Human and Intentional vs. Unintentional) in a French population. The results show that the social representation is organized around five potentially central descriptive, anxiety-provoking and globally negative elements. But death and contagion are the only stable and structuring elements. The other elements vary according to the reason attributed to the object of fear. Depending on how individuals attribute the origin of the virus, social representations of it vary not only in terms of their content but also in terms of their structure. These results indicate how important it is to consider the perceptions that individuals share about the human (vs. non-human) and intentional (vs. unintentional) origin of an object of fear in the analysis of their representation of that object.
\end{abstract}

Key-words: Social Representations, Collective Fear, Covid-19, Social Thinking, France 


\section{Introduction}

Collective beliefs are notably at work in pandemics and the one we are currently facing (i.e., Coronavirus-Covid19) inevitably questions the collective fears generated by viral contamination and their links with its social representations. The notion of "fear" plays a prominent role in the collective consciousness of the 21st century (Delouvée et al., 2013) and several academic works have been devoted to it. But whether it is a question of studying the rise of risk awareness (Slovic, 1987), fear of the urban environment (Ellin, 2001), fear of crime (Garland, 2001), fear of the Other (Salecl, 2004), the amplification of fear through the media (Altheide, 2002), the impact of fear on laws (Guzelian, 2004), the relationship between fear and politics (Füredi, 2006; Robin, 2004), the question of fear as a cultural form in its own right (Tudor, 2003) or, more recently, the fear of the COVID-19 (Ng \& Kemp, 2020), the latter is always examined in a specific and particular context and is only rarely considered as a global and unified sociological phenomenon in itself. Thus, as Hankiss (2001) points out, despite the number of works devoted to it, efforts to theorize the notion of collective fear are still very much neglected by the social sciences (e.g., Brewer et al., 2007; Brewin et al., 2000; Franklin et al., 2017).

In addition, it appears that in much of the research on risk, this notion is interchangeable with the notion of collective fear (e.g., Cohen, 2002; Furedi, 2007; Lerner \& Keltner, 2001; Lupton, 1999; Pidgeon, Kasperson \& Slovic, 2003; Slovic, 2000). Finally, in several contributions, fear is studied only as an emotional experience of risk, at a strictly intraindividual level (e.g., Power, 2007; Guénin-Paracini, Malsch \& Paillé, 2014).

This is why Rouquette $(2009,2007)$ proposed an original taxonomy of collective fears in order to reintegrate and conceptualize this notion into the social sciences. Its basic idea is that an object of fear and the "reason" attributed to it by individuals and groups are two different things. The same event can take on several meanings depending on the social group or, within 
the same social group, depending on moments in its history (e.g., Gruev-Vintila and Rouquette, 2007). This is particularly the case for most epidemics and natural disasters (HIV/AIDS, leprosy, floods, famine, etc.) which, depending on the group and the time in history, may have been considered as a divine punishment for moral misconduct, a just consequence of imprudent practices, or a simple public health problem, without any underlying intention (Páez et al., 1991; Stuber, 2003; Valdiserri, 1987; Washer and Joffe, 2006).

Thus, and whether in reality or in the imagination, the origin of disturbing or frightening events can be broken down into four categories according to the author (Table 1 systematizes these configurations):

- Direct human intervention: the catastrophic event is considered to be due to the action, official or hidden, of "sorcerer's apprentices", "agents of evil", cruel or perverse enemies (e.g., terrorist attacks).

- Indirect human intervention: the event appears here as a feedback effect of technical progress or a particular economic policy that is generally judged negatively (e.g., global warming).

- Non-human intervention: it is a punishment from God as a result of a fault, or a Martian attack.

- Finally, there is no assignable intentional intervention (whether man-made or not): the catastrophe is a statistical variation, an accidental coincidence. In short, it occurs "without reason".

---- Insert Table 1 here ----

These different scenarios can be expressed differentially in the socio-cognitive treatment of the same catastrophic event or the same object of fear. 
For example, let us consider a famous and recurrent object of collective fear: famine or scarcity (Dijkman \& Van Leeuwen, 2020).

According to the groups, it could be attributed:

A - To starvers

D - To poor harvests following bad weather

B - To God's punishment for one fault or another

$\mathrm{C}$ - To the negligence of the government (which has failed to create stocks, etc.).

The same object of fear can therefore mobilize several types of causality, alternative or competing, which can be attributed to one of the four cases defined above. However, we can think that these causal attributions are anchored in social representations that are themselves differentiated with regard to the object of fear.

Our objective is twofold: on the one hand, to better understand the existence of differentiated perceptions of the same object of fear according to the attribution of its origins; on the other hand, to identify applications in terms of preventive communication in public health.

\section{Theoretical framework}

Rouquette (1973) proposed the term "social thought" to describe both the specificity of thought when it takes as its object a social phenomenon, and the constitutive determination of this thought by social factors. To study social thought is therefore to consider that all forms of social knowledge are body and meaning. They are integrated because the cognitive processes that underlie them are deeply interrelated and do not appear at random. They make sense because their occurrence, in relation to a given object, is almost always the hallmark of a particular social position. 
In the same line, Garland (2001) notes that our fears, and most of our ways of understanding them, are based on social facts and are supported by "cultural scripts". This idea of a cultural script is very close to the notion of social representation developed by Moscovici (2008, 1961).

For this author, social representations are socio-cognitive constructs that reformulate the environment of individuals so that they appropriate it. It is a form of knowledge, socially elaborated and shared, having a practical aim and contributing to the construction of a common reality common for a social group. It allows individuals to interpret the world around them through a relatively common filter that will also guide their actions. According to their representations, individuals will, on the one hand, have an attitude, take a position towards an object, and on the other hand, carry out behaviours in coherence with these representations. For this reason, representation is the basis of most of our behaviour. But it also determines our communications, as well as the form and content of our interactions. The processing of information will also be subject to our social representations. Social representations therefore go beyond simple beliefs. They are collectively constructed knowledge systems that determine social position, behaviours, communications, the way information is processed and even the identity of individuals and group.

At the origin of the emergence of a social representation, we generally find a new social situation, an unknown phenomenon or a conflict that disrupts the practices of a community. The novelty of the object or phenomenon means that information about it is at once limited, insufficient or incomplete and overabundant, especially in the media space. It is necessary for individuals to develop a precise knowledge of this new and important object in order to master it. To do this, they must evaluate their opinions about the new context and compare them with those of other members of their group. Through collective and public communications, this process reflects a social dynamic that will lead to the establishment of a 
majority position shared by most members of a given group. To develop this majority position, individuals will have to process information about the object or situation selectively, focusing on a particular aspect according to the expectations and orientations of their group. This newly emerging majority position within the group is a new social representation.

However, Moscovici's $(1961,2008)$ proposes that three minimum conditions have to be satisfied for the establishment of a social representation structure: a social object must be ambiguously defined, people should feel the need to infer about it, and different aspects of that object should be salient for different groups. These three conditions are met in the event of a viral pandemic (Eicher \& Bangerter, 2015).

Joffe and Haarhoff (2002), analysing how the British press reported the Ebola epidemic in Africa in the mid-1990s, shows that the Ebola virus was represented as African and seen as posing little threat to Britain. The social representations of infectious diseases were analysed through the example of far-off diseases. Ribeiro, Hartley, Nerlich and Jaspal (2018) also analyzed the press and social representations of an emerging infectious disease (Zika) to a directly affected population (Brazilians). The analysis revealed a dominant 'war' frame supported by two sub-frames (eradicating the vector and controlling microcephaly). This 'war' frame gave prominence and legitimacy to certain representations of disease management during the crisis, masking social and gender inequalities. From a theoretical point of view, Flament and Rouquette (2003) added that an object must have a concept function for the group, explaining a set of occurrences of subordinate phenomena; it must be a communication topic; and it must be associated with a level of social practices. Coronavirus meets all of these conditions. We have therefore focused on studying its social representations within the framework of the structural approach known as the Central Core Theory (see Rateau et al., 2011 for a review). 
This theory postulates that a social representation is a hierarchized and organized system, composed of two interactive sub-systems: a central system and a peripheral system. The central system (or central core) includes a limited number of elements which constitute the common and consensual base of the collective memory and the system of norms to which a group refers (Abric, 2001). It is consensual, stable, coherent, and not very sensitive to the immediate context. Furthermore, the central system generates the signification of the representation and determines its organization (Abric, 1993). It constitutes the heart of the representation. The peripheral system itself is composed of elements which give a concrete expression to and illustrate the representation. They are more diverse and flexible than the central core elements. They are the elements most present quantitatively and which appear as an interface between the central core and concrete situations. To study a social representation is therefore to study the organization of the elements of knowledge that compose it, and to identify, among these elements, which are the central ones, which constitute the core of meanings conferred to the object by the group.

The aim of this study is to examine how perceptions of the initial reasons for the object of fear (i.e., COVID-19) are anchored in differentiated social representations of the object. These differences should be expressed at the level of their structural organization as well as at the level of their valence (positive vs. negative). From a theoretical point of view, these results would indicate that differences in the attribution of the origin of an object of fear are strongly linked to the development of different social representations of this object. Taking these attributions into account would then prove to be crucial in order to grasp the meaning that individuals co-construct of the object.

From a more applied perspective, these results would make it possible to draw up recommendations for public health prevention campaigns. Prevention approaches reflect values or behaviours that one wishes to promote. These values and behaviours always have an 
appearance of consensus, but the reality is quite different. The dissemination of prevention messages always comes up against the filters of the perception of individuals and groups, which regulate the information in order to match it with their systems of representation (cf. Aim et al., 2018; Dany \& Apostolidis, 2002; Joffe, 2002; Justo et al., 2020). Assigning different meanings to a pandemic implies different degrees of adherence to infection control practices. Considering and understanding these differences is therefore a crucial issue in the development of prevention campaigns.

\section{Method}

\subsection{Participants and Procedure}

The study took the form of an online questionnaire distributed via social networks. $89 \%$ of the French population is connected to the Internet in France and 39 million Internet users actively use social networks. It is on these same social networks that a large number of fake news, rumors and other conspiracy theories circulate, especially about the Covid-19 pandemic (Bertin et al., 2020; Pennycook et al., 2020). If the population is not representative of the French population in the strictly statistical sense, it is however a good reflection of it and the sample was large. 1144 participants completed the questionnaire $\left(M_{\text {age }}=32.47 ; S D=15.15\right)$ between 26 March and 2 April 2020. The sample size far exceeded the recommendations of Schönbrodt and Perugini (2013). Participants under the age of majority, and those who took an unusually long or short time (mean plus/minus $1 \mathrm{SD}$ ) to complete the questionnaire were excluded from the analysis. The final sample consisted of 1060 participants $\left(M_{\text {age }}=32.43\right.$; $S D=14.76$, age range: 18 to 84 years; $77.99 \%$ were women). After freely consenting to participate in the study, participants provided some socio-demographic information (gender and age) and then completed a measure of causal perception of the Coronavirus, and a free association task. 


\subsection{Measures}

Causal perception of Coronavirus. Participants were asked to choose one of four statements that best explained the emergence of the virus (i.e., it was created by man for a malevolent purpose: it was created by mankind by mistake through a faulty manoeuvre; it was a deliberate revenge of Nature; it was the unfortunate result of a combination of natural circumstances).

Free association task (Lo Monaco et al., 2017; Vergès, 1992). Participants had to produce the 4 words or expressions that came to mind when they thought of the inducer, namely "Coronavirus - Covid 19".

Valence. They then had to evaluate the valence of each of their answers. Participants provided their answers on a 7-point Likert scale ranging from -3 (completely negative) to +3 (completely positive). We calculated an average composite score: the higher the score, the more positive the attitude associated with the evocations.

\subsection{Statistical Appendix}

In addition to the diversity index (Flament \& Rouquette, 2003) used and defined below, we used statistical tests to compare means: Student's $t$ and the ANOVA. Student's $t$ test allows us to compare a mean from one normal distribution to a value if the variance is unknown or to compare two means from two normal distributions if their variances are equal and unknown (Loewenthal \& Lewis, 2001). The Analysis of Variance (ANOVA) is also a parametric test for comparing means that is applied when measuring one or more categorical explanatory variables. A "post-hoc" test (Multiple Comparison Test) is used to compare the ANOVA samples in pairs. Here we used one common and popular method of post-hoc analysis is Tukey's Test (Howell, 2012). Finally, when the F value was significant, we calculated the partial eta-squared index ( $\eta^{2}$ partial). This index corresponds to a measure of 
effect size. The partial eta-squared value indicates the proportion of the specific variance explained by the factor when the effect of the other factors is controlled.

\section{Results}

\subsection{Social representations}

The social representation of the Coronavirus was studied on the basis of free associations produced and analysed using the rank-frequency method (Lo Monaco et al., 2017). As a reminder, each participant was invited to produce the 4 words or expressions that came to mind when they thought of the "Coronavirus - Covid 19". For each term produced, we therefore have two indexes: its frequency of appearance in the corpus and its average rank of appearance (from 1 to 4 ) in the associations produced by each participant. Then the method consists in considering and crossing two indicators: the frequency of an item and its spontaneous appearance ranking (from 1, cited first, to 4 cited last). Cross-tabulation of these two criteria produced a four-cell table which represents four distinct zones of the representation (Table 2).

---- Insert Table 2 here ----

Cell 1 contains the most frequent (high frequency) and first-cited terms (i.e., with a low average rank, close to one) for the population being studied. These elements have a high probability of belonging to the central core. This zone is called "the core zone". Cell 4 (periphery) contains the terms least frequently cited (low frequency) and cited last (high average rank, close to 4). Cells 2 and 3 (potential change zones, give seemingly contradictory information. In one case (Cell 3) the words are cited first (i.e., low average rank) but their frequency is low, in the other (Cell 2), the high frequencies do not compensate for a much lower ranking. These two cells constitute a potentially destabilizing zone, a source of change, and of the development of reasoned arguments. 
The total corpus of the 4240 associations produced was lemmatized and categorized (e.g., Lambert et al., 2009) into 174 different semantic units. We first calculated a diversity index (Flament and Rouquette, 2003) corresponding to the ratio between the total number of units $(\mathrm{n}=174)$ and the total number of evocations collected $(\mathrm{N}=4240)$. This index, which can theoretically vary between 0 and 1 , is low (0.04) which indicates a strong convergence of responses and the sign of a representation strongly crystallized around a small number of elements.

Only units with a frequency of occurrence greater than 30 were then considered, i.e., 28 units covering 3693 occurrences (87.07\% of the total corpus). This final corpus was divided into two parts: on the one hand, according to the mean of the distribution of frequencies of appearance of each unit $(\mathrm{M}=131)$ and, on the other hand, according to the mean of the ranks of the distribution of the ranks of appearance of each unit $(\mathrm{M}=2.67)$. Cross-tabulation of these two criteria produced a four-cell table which represents the four distinct zones of the representation (Table 3).

- Insert Table 3 here ----

We observe that the social representation of the Coronavirus in the global population is organized around five potentially central elements: Contagion, Lockdown, Fear, Death and Disease. With a mean valence of $-1.63(\mathrm{SD}=1.70)$, this central zone appears to be very negative (One sample T-test with Test Value $=0 ; t(2071)=-43.54, \mathrm{p} .<.001)$.

The sample was then split into four based on the responses provided regarding causal perceptions: Human Intentional $(\mathrm{N}=84)$ vs. Human Unintentional $(\mathrm{N}=112)$ vs. Non-Human Intentional $(\mathrm{N}=133)$ vs. Non-Human Unintentional $(\mathrm{N}=731)$. In each of these samples, the representation was analyzed on the basis of the semantic units listed above. 


\subsection{Human Intentional}

The total corpus of the 336 associations here covers 56 of the 174 previous semantic units. The diversity index (56/336) is low (0.17) which indicates a strong convergence of responses and the sign of a representation strongly crystallized around a small number of elements.

Only units with a frequency of occurrence greater than 4 were then considered, i.e., 17 units covering 264 occurrences ( $78.57 \%$ of the corpus). This corpus was divided into two parts: On the one hand, according to the mean of the distribution of frequencies of appearance of each unit $(\mathrm{M}=15.52)$ and, on the other hand, according to the mean of the ranks of the distribution of the ranks of appearance of each unit $(\mathrm{M}=2.65)$. Cross-tabulation of these two criteria produced a four-cell table which represents the four distinct zones of the representation (Table 4).

---- Insert Table 4 here ----

In this sample, we observe that the social representation of the Coronavirus is organized around five potentially central elements: Contagion, Lockdown, Fear, Death and Conspiracy. This last unit was in a zone of change in the overall representation. We also note that two units that are part of the periphery of the global representation, here integrate the zones of change: Mismanagement and Chinese. The unit Barrier gestures appears to be peripheral as it appeared in a zone of change in the overall representation. Finally, the unit Disease appears to be in a zone of change as it appeared previously in the central zone. 


\subsection{Human Unintentional}

The total corpus of the 448 associations here covers 55 of the 174 previous semantic units. The diversity index (55/448) is low (0.12) which indicates a strong convergence of responses and the sign of a representation strongly crystallized around a small number of elements.

Only units with a frequency of occurrence greater than 21 were then considered, i.e., 19 units covering 382 occurrences ( $85.26 \%$ of the corpus). This corpus was divided into two parts: On the one hand, according to the mean of the distribution of frequencies of appearance of each unit $(\mathrm{M}=20.10)$ and, on the other hand, according to the mean of the ranks of the distribution of the ranks of appearance of each unit $(\mathrm{M}=2.54)$. Cross-tabulation of these two criteria produced a four-cell table which represents the four distinct zones of the representation (Table $5)$.

Insert Table 5 here ----

In this sample, we observe that the social representation of the Coronavirus is organized around three potentially central elements: Contagion, Death and Disease. There are two noteworthy movements: Two units that are part of the central zone of the global representation here integrate a zone of change: Lockdown and Fear. Furthermore, the units Chinese, Mismanagement and Irresponsibility appear to be in a zone of change as they appeared in the peripheral zone in the overall representation. 


\subsection{Non-Human Intentional}

The total corpus of the 532 associations here covers 80 of the 174 previous semantic units. The diversity index $(80 / 532)$ is low $(0.15)$ which indicates once again a strong convergence of responses and the sign of a representation strongly crystallized around a small number of elements.

Only units with a frequency of occurrence greater than 31 were then considered, i.e., 14 units covering 431 occurrences ( $81 \%$ of the corpus). As above, the corpus was divided into two parts: on the one hand, according to the mean of the distribution of frequencies of appearance of each unit $(\mathrm{M}=30.78)$ and, on the other hand, according to the mean of the ranks of the distribution of the ranks of appearance of each unit $(\mathrm{M}=2.63)$. Cross-tabulation of these two criteria produced a four-cell table which represents the four distinct zones of the representation (Table 6).

Insert Table 6 here ----

In this sample, we observe that the social representation of the Coronavirus is organized around three potentially central elements: Contagion, Death and Lockdown. We also note that two units that are part of the central zone of the global representation here integrate a zone of change: Fear and Disease. Finally, the units Awareness and Solidarity appear to be in a zone of change as they appeared in the peripheral zone in the overall representation. 


\subsection{Non-Human Unintentional}

The total corpus of the 2924 associations here covers 130 of the 174 previous semantic units. The diversity index (130/2924) is very low (0.04) which indicates once again a strong convergence of responses and the sign of a representation strongly crystallized around a small number of elements.

Only units with a frequency of occurrence greater than 109 were then considered, i.e., 22 units covering 2400 occurrences ( $82 \%$ of the corpus). As above, the corpus was divided into two parts: on the one hand, according to the mean of the distribution of frequencies of appearance of each unit $(\mathrm{M}=109.09)$ and, on the other hand, according to the mean of the ranks of the distribution of the ranks of appearance of each unit $(M=2.68)$. Cross-tabulation of these two criteria produced a four-cell table which represents the four distinct zones of the representation (Table 7).

Insert Table 7 here ----

The social representation of the Coronavirus is here organized around the same potentially central elements as in the overall representation. This seems normal since this sample is the largest of the four. It therefore contributes more significantly to the overall representation of the population studied here. Some important displacements should however be noted: Pulmonary is here in the peripheral zone and some units disappear completely from the structural organization. This is notably the case of Conspiracy, present in the three other samples. 
If we consider all the representations analysed, we observe that only two elements are always part of the zone of centrality: Contagion and Death. For this reason, we think that these two elements are undoubtedly part of the central core of the Coronavirus representation and constitute its priority elements (Rateau, 1995a, 1995b; Wachelke, 2012). With the exception of the group for which the origin of the virus is Non-Human and Unintentional, the other three representations are distinguished either by the absence of one or more elements from the core area of the overall representation (Fear and Disease for the Unintentional Non-Human group; Fear and Lockdown for the Unintentional Human group; Disease for the Intentional Human group), or by the presence of an additional element (Conspiracy for the Intentional Human group).

\subsection{Valences of the core zones}

On the other hand, the tonality associated with the core zone of each of the four representations, measured using the valence scales, gives rise to several differences (Table 8).

---- Insert Table 8 here ----

We conducted an independent measure analysis of variance with Humanity and Intentionality as independent variables, and Valence of the score zone as the dependent variable. This indicated that a Human attribution of the virus $(\mathrm{N}=321, \mathrm{M}=-1.87, \mathrm{SD}=1.80)$ was associated with a more negative core zone than a Non-human attribution $(\mathrm{N}=1751, \mathrm{M}=$ 1.58; $\mathrm{SD}=1.68): F(1,2068)=13.62, p<.001, \eta_{p}{ }^{2}=0.007$ 
It also indicated that an Intentional attribution $(\mathrm{N}=386, M=-1.49, S D=1.94)$ was associated with a less negative core zone than an Unintentional attribution $(\mathrm{N}=1686, \mathrm{M}=-1.66, \mathrm{SD}=$ 1.64): $F(1,2068)=10.17, p=.005, \eta_{p}^{2}=0.005$.

The interaction was not significant $(\mathrm{F}(1,2068)<1)$.

Post-hoc Tukey tests indicated that the core zone was more negative in the Human Unintentional group $(\mathrm{N}=143, \mathrm{M}=-2.12, \mathrm{SD}=1.43)$ than in the Non-Human Unintentional group $(\mathrm{N}=1543, \mathrm{M}=-1.61, \mathrm{SD}=1.65): t=-3.43, p_{\text {Tukey }}=.003$. It also indicated that the core zone was more negative in the Human Unintentional group $(\mathrm{N}=143, \mathrm{M}=-2.12, \mathrm{SD}=1.43)$ than in the Non-Human Intentional group $(\mathrm{N}=208, \mathrm{M}=-1.34, \mathrm{SD}=1.86): t=-4.25, p_{\text {Tukey }}<$ .001

We performed the same analyses on each of the two elements common to all four groups: Death and Contagion. No significant effect was found. Therefore, these two elements are associated with the same negative valence in each of the four groups.

\subsection{Prototypicality Index}

We recall that the central elements constitute the core of the meanings conferred to the object by the group. It was therefore important to consider the extent to which the central elements of the general representation are present in the differentiated representations according to the perceived origin of the object of fear. To do this, we noted for each participant the number of evocations relevant to the central core of the overall representation that he or she had produced. Thus, this index varies from 0 to 4 . In this way, we evaluated "the appeal to the core zone" that each subject makes when producing these associative responses. By considering the average number of "calls for centrality" in each of the groups, we thus defined 
an index of prototypicality of the central area of each group in relation to the general representation of the whole population. Results are presented in Figure 1.

---- Insert Fig. 1 here ----

An independent measure analysis of variance with Humanity and Intentionality as independent variables, and prototypicality index as the dependent variable was performed (Fig. 1). This indicated that an Intentional attribution of the virus $(\mathrm{M}=1.97, \mathrm{SD}=1.15)$ was associated with less prototypicality of the core zone than an Unintentional attribution $(\mathrm{M}=$

$2.14, \mathrm{SD}=1.07): F(1,1056)=8.33, p=.004, \eta_{p}{ }^{2}=0.008$. The effect of the Human (vs. NonHuman) attribution was not significant: $F(1,1056)<1$.

On the other hand, the effect of the interaction was significant $\left(F(1,1056)=4.44, \mathrm{p}=.03, \eta_{p}^{2}\right.$ $=0.004)$ in the sense that the effect of the perception of intentionality of the origin of the virus on the relative weakness of prototypicality of the centrality zone is reinforced when this intentionality is considered human.

Furthermore, post-hoc Tukey tests indicated that the core zone was less prototypical in the Human Intentional group $(\mathrm{M}=1.86, \mathrm{SD}=1.17)$ than in the Human Unintentional group $(\mathrm{M}=$ 2.33, $\mathrm{SD}=1.17): t=-2.98, p_{\text {Tukey }}=.01$.

\section{Discussion}

The aim of this study was, on the one hand, to analyse the social representation of the Coronavirus in a wide population in the context of the sudden appearance of the contagion and, on the other hand, to study possible differentiated representations according to the origins attributed to the appearance of the virus. 
With regard to the first point, the results indicated a representation organized around five potentially central elements: contagion, fear, death, lockdown and disease. This zone of centrality is quite descriptive, anxiety-provoking and globally negative. However, only two elements seemed to be stable and potentially organizing elements of the representation: death and contagion. The other elements will indeed fluctuate according to the reasons attributed to the object of fear: human vs. non-human origin, intentional vs. non-intentional. We will recall here that according to the central core theory, two social representations will be considered as different when they do not share the same central system (Abric, 1993). We must therefore note the existence of four differentiated representations according to the origins attributed to the Coronavirus since, despite the common presence of the elements Death and Contagion, the zones of centrality of each will present specificities.

In the case of the perception of a non-human and non-intentional origin (the most frequent within our population), the five elements previously described constitute the zone of centrality.

The perception of a non-human but intentional origin reduced the zone of centrality to three elements: Death, Contagion and Lockdown. The terms Fear and Disease were found here outside the potential core.

In the case of a Human but unintentional perception of the origin of the Coronavirus, it was still a zone of centrality with three elements that emerged, but here it was the notion of Disease that was associated with Death and Contagion. The elements Fear and Lockdown were no longer part of the potential core.

Finally, for individuals who believe that the origin of the virus is human and intentional, the representation was organized around the two elements common to the whole, Lockdown, Fear and a specific and particular element: Conspiracy. We also noted the appearance, in the first periphery, of the term Mismanagement. This sample also stood out by the fact that it is the 
one which, during the associative phase, draws the least from the central zone of the general population when it comes to evoking the Coronavirus. This sample is therefore the one that differs the most from the majority knowledge about the object.

Finally, we observed that the attitude towards the object of fear, measured here by a valence index of the associated terms, proved to be sensitive to the variables studied. The perception of a human origin of the object of fear is closely linked to a more negative attitude towards it than the perception of a non-human origin. In the same way, the perception of an unintentional character of the object of fear is associated with a negative attitude towards it.

In the end, this study indicates the value of considering the differentiated attributions that individuals make about collective objects of fear. These appear to be linked to differentiated social representations and differentiated attitudes towards the object. We think this study advantageously complements work carried out on disasters caused solely by human intervention (see Erikson, 1994, for example about technological disasters) and defines $a$ priori as such. Because it shows that the crucial factor in the way individuals will apprehend the event is the categorization they themselves make of its origin.

In terms of application, this study alerts us to the importance of carefully considering the way in which individuals construct their own representations of objects of fear according to the origin they attribute to these objects. This is particularly crucial in the context of public health prevention communications. Many studies have shown how much more effective it is to focus preventive and persuasive communications on core elements of the representations (Lo Moncao, Girandola and Guimelli, 2016; Bonetto, Girandola and Lo Monaco, 2018, 2020). To determine the differentiated representations that groups share of the object and, in particular, to identify the central elements of these representations appear to be critical in deploying relevant and effective prevention messages. 
An example is a public health campaign advocating the widespread vaccination against Covid-19. According to our results, this campaign would benefit from the fact that vaccination would greatly reduce contagion and mortality rates (common central elements) rather than arguments based on solidarity with the most vulnerable people (peripheral elements). However, our results also indicate that individuals who believe that the virus is man-made and intentionally manufactured develop a social representation that incorporates a central conspiratorial view of Covid-19. There is here a high probability that the effectiveness of a vaccination promotion campaign will be undermined. Indeed, it is known that vaccine hesitancy is strongly linked to adherence to conspiracy theories that discredit science (Jolley \& Douglas, 2014, 2017; Hornsey, Harris \& Fielding, 2019; Chen, Zhang, Young, Wu \& Zhu, 2020). To think that the virus is intentionally manufactured and man-made and to develop a representation of covid-19 organised around the central notion of conspiracy would discredit the adherence to a widespread vaccination campaign promoted by a public health organisation, undoubtedly suspected of being an integral part of this conspiracy (Marinthe, Brown, Delouvée \& Jolley, 2020). Indeed, it is known that beliefs in conspiracy theories harbor intergroup categorization (Kofta \& Sedek, 2005; Bilewicz, Winiewski, Kofta \& Wójcik, 2013). For this section of individuals, it can be assumed that the impact of such a campaign would probably be more decisive if it were relayed by general practitioners, pharmacists or social contacts who have been vaccinated, playing the role of ambassadors. This is also indicated by the recent results of the barometer of vaccination motivation published by the Psychology and Corona group of Ghent University in collaboration with the Catholic University of Leuven and the Free University of Brussels (2020). In any case, our results make us reflect on the implementation of specific forms of prevention that take into account the beliefs and representations of the target groups. 
Finally, and as an extension, we can think that another point of interest concerns the perception that individuals share of the reversibility of a given fear situation. This perception, which is important in the context of socio-representational dynamics (Flament, 1994; Tafani and Souchet, 2002), is of particular interest with regard to the representation of objects of fear. Rightly or wrongly, it does not matter, individuals can indeed consider that the situation generated by the anxiety-producing object (new adaptive practices, new frames of thinking, etc.) can be permanent or, on the contrary, only temporary. We can then think that the social representations shared with regard to the object will be also impacted by this perception.

\section{Ethics Statement}

The university of the leading authors does not have institutional review boards for psychology or social science research. We thus applied the 1964 Helsinki Declaration and its later amendments (2001), the ethical principles of the French Code of Ethics for Psychologists (2012), and the American Psychological Association Ethical Principles of Psychologists and Code of Conduct (2017). Participants were informed about the purpose of the study in a cover letter and were assured that their data would remain confidential. Participants had to give explicit consent to access the study. All research materials were uploaded to the Open Science Framework (https://osf.io/zhr6v/?view_only=1e507daacf81465eb01df85f7cecf644). 


\section{References}

Abric, J.-C., 1993. Central System, Peripheral System: their functions and roles in the dynamics of social représentations. Pap. Soc. Represent. 2, 75-78. http://psr.iscteiul.pt/index.php/PSR/article/view/126

Abric, J., 2001. A Structural Approach to Social Representations, in: Deaux, K., Philogène, G. (Eds.), Representations of the Social: Bridging Theoretical Traditions. Blackwell, Oxford, pp. 42-47.

Altheide, D.L., 2002. Creating Fear: News and the Construction of Crisis. Aldine de Gruyter, New York.

Aim, M.A., Lelaurain, S., Khatmi, N., Fonte, D., Bovina, I., Dany, L. 2018. 'Similar but different' : Social representations of health according to gender for French youth. J. Health Psychol., 25(12), 1905-1916. https://doi.org/10.1177/1359105318781894

Bertin, P., Nera, K., Delouvée, S. 2020. Conspiracy Beliefs, Rejection of Vaccination, and Support for hydroxychloroquine: A Conceptual Replication-Extension in the COVID-19 Pandemic Context. Front. Psychol., 11, 2471. https://doi.org/10.3389/fpsyg.2020.565128

Bilewixz, M., Winiewski, M., Kofta, M., Wójcik, A., 2013. Harmful ideas, the structure and consequences of anti-semitic bleiefs in Poland. Polit. Psychol. 34(6), 821-839. https://doi.org/10.1111/pops.12024

Brewer, N.T., Chapman, G.B., Gibbons, F.X., Gerrard, M., McCaul, K.D., Weinstein, N.D., 2007. Meta-analysis of the relationship between risk perception and health behavior: The example of vaccination. Health Psychol. 26, 136-145. https://doi.org/10.1037/0278$\underline{6133.26 .2 .136}$

Brewin, C.R., Andrews, B., Valentine, J.D., 2000. Meta-analysis of risk factors for posttraumatic stress disorder in trauma-exposed adults. J. Consult. Clin. Psychol. 68, 748-766. https://doi.org/10.1037/0022-006X.68.5.748

Bonetto, E., Girandola, F., Lo Monaco, G., 2018. Social representations and commitment: A literature review and an agenda for future research. Eur. Psychol., 23, 233-249. https://doi.org/10.1027/1016-9040/a000317

Bonetto, E., Girandola, F., Lo Monaco, G., 2020. The social value of social representations: Replication of previous findings and test of novel hypotheses. Soc. Sci. J. https://doi.org/10.1080/03623319.2020.1727241 
Chen, L., Zhang, Y., Young, R., Wu, X., Zhu, G., 2020. Effects of Vaccine-related Conspiracy Theories on Chinese Young Adults' Perceptions of the HPV Vaccine: An Experimental Study. Health Commun., 1-11. https://doi.org/10.1080/10410236.2020.1751384

Cohen, S., 2002. Folk Devils and Moral Panics. The Creation of the Mods and Rockers. Routledge, New York.

Dany, L., Apostolidis, T., 2002. L'étude des représentations sociales de la drogue et du cannabis : un enjeu pour la prévention. Santé Publique, 4(14), 335-344. https://doi.org/10.3917/spub.024.0335

Delouvée, S., Rateau, P., Rouquette, M.-L., 2013. Les Peurs Collectives. Perspectives Psychosociales. Erès, Toulouse.

Dijkman, J., Van Leeuwen, B., 2020. An economic history of famine resilience. Routledge, New York.

Eicher, V., Bangerter, A., 2015. Social representations of infectious diseases, in: Sammut, G., Andreouli, E., Gaskell, G. (Eds.), Societal Psychology: A Handbook of Social Representations. Cambridge University Press, Cambridge, pp. 385-396.

Ellin, N., 2001. Thresholds of fear: Embracing the urban shadow. Urban Stud. 38, 869-883. https://doi.org/10.1080/00420980124399

Erikson, K. T., 1994. A new species of trouble. W.W. Norton, New-York.

Flament, C., 1994. Structure, dynamique et transformation des représentations sociales, in: Abric, J.-C. (Ed.), Pratiques Sociales et Représentations. Presses Universitaires de France, Paris, pp. 37-57.

Flament, C., Rouquette, M.-L., 2003. Anatomie des idées ordinaires. Comment étudier les représentations sociales. Armand Colin, Paris.

Franklin, J.C., Ribeiro, J.D., Fox, K.R., Bentley, K.H., Kleiman, E.M., Huang, X., Musacchio, K.M., Jaroszewski, A.C., Chang, B.P., Nock, M.K., 2017. Risk factors for suicidal thoughts and behaviors: A meta-analysis of 50 years of research. Psychol. Bull. 143, 187-232. https://doi.org/10.1037/bul0000084

Furedi, F., 2006. Culture of Fear Revisited. Risk-taking and the Morality of Low Expectation. Continuum, New York. 
Furedi, F. 2007. The only thing we have to fear is 'the culture of fear' iteself. Spiked. http://www.spiked-online.com/newsite/article/3053\#.Ui4VbRbbWQs

Garland, D., 2001. The Culture of Control. Crime and Social Order in Contemporary Society. Oxford University Press, Oxford. https://doi.org/10.1515/mks-2003-0036

Gruev-Vintila, A., Rouquette, M.-L., 2007. Social Thinking about Collective Risk: How Do Risk-related Practice and Personal Involvement Impact Its Social Representations? J. Risk Res. 10, 555-581. https://doi.org/10.1080/13669870701338064

Guénin-Paracini, H., Malsch, B., \& Paillé, A.M., 2014. Fear and risk in the audit process. Account. Org. Soc., 39(4), 264-288. 10.1016/j.aos.2014.02.001

Guzelian, C., 2004. Liability \& Fear. Ohio State Law J. 65, 713-851.

Hankiss, E., 2001. Fears and Symbols. An Introduction to the Study of Western Civilization. Plymbridge Distributors Ltd., Plymouth.

Hornsey, M., Harris, E., Fielding, K., 2019. The psychological roots of anti-vaccination attitudes: A 24-nation investigation. Health Psychol., 37(4), 307-315. DOI: $10.1037 /$ hea0000586

Howell, D. C., 2012. Statistical methods for psychology. Cengage Learning.

Joffe, H., 2002. Social representations and health psychology. Soc. Sci. Info., 41(4), 559-580. DOI: $10.1177 / 0539018402041004004$

Joffe, H., Haarhoff, G., 2002. Representations of far-flung illnesses: The case of Ebola in Britain. Soc. Sci. Med. 54, 955-969. https://doi.org/10.1016/S0277-9536(01)00068-5

Jolley, D., Douglas, K.M,, 2014. The Effects of Anti-Vaccine Conspiracy Theories on Vaccination Intentions. PLoS One. https://doi.org/10.1371/journal.pone.0089177

Jolley, D., Douglas, K. M., 2017. Prevention is better than cure: Addressing anti-vaccine conspiracy theories. J. Appl. Soc. Psychol., 47(8), 459-469. https://doi.org/10.1111/jasp.12453

Justo, A.M., Bousfield, A.B., Giacomozzi, A.I., Camargo, B.V., 2020. Communication, social representations and prevention. Information polarization on COVID-19 in Brazil. Pap. Soc. Repr. http://psr.iscte-iul.pt/index.php/PSR/article/view/533

Kofta, M., Sedek, G., 2005. Conspiracy stereotypes of Jews during systemic transformation in Poland. Int. J. of Sociol., 35(1), 40-64. doi:10.1080/00207659.2005.11043142 
Lambert, N.M., Graham, S.M., Fincham, F.D., 2009. A prototype analysis of gratitude: varieties of gratitude experiences. Personal. Soc. Psychol. Bull. 35, 1193-1207. https://doi.org/10.1177/0146167209338071

Lerner, J.S., Keltner, D., 2001. Fear, Anger, and Risk. J. Pers. Soc. Psychol. 81, 146-159. https://doi.org/10.1037/0022-3514.81.1.146

Lo Monaco, G., Girandola, F., Guimelli, C., 2016. Experiments inter-connecting the structure of social representations, cognitive dissonance, commitment and persuasion: past, present and future. Pap. Soc. Rep., 25(2), 5-1. http://psr.iscteiul.pt/index.php/PSR/article/view/42

Lo Monaco, G., Piermattéo, A., Rateau, P., Tavani, J.L., 2017. Methods for Studying the Structure of Social Representations: A Critical Review and Agenda for Future Research. J. Theor. Soc. Behav. 47, 306-331. https://doi.org/10.1111/jtsb.12124

Lupton, D., 1999. Risk and Sociocultural Theory : New Directions and Perspectives. Cambridge University Press, Cambridge.

Loewenthal, K. M., \& Lewis, C. A. (2001). An introduction to psychological tests and scales. Psychology press.

Marinthe, G., Brown, G., Delouvée, S., Jolley, D., 2020. Looking out for myself: Eploring the relationship between conspiracy mentality, perceived personal risk, and COVID-19 prevention measures. Brit. J. Health. Psychol., 25(4). https://doi.org/10.1111/bjhp.12449

Moliner, P., Lo Monaco, G., 2017. Méthode d'association verbale pour les sciences humaines et sociales. Fondements conceptuels et aspects pratiques. Presses Universitaires de Grenoble, Grenoble.

Moscovici, S., 1961. La psychanalyse, son image et son public. Presses Universitaires de France, Paris.

Moscovici, S., 2008. Psychoanalysis: Its image and its public. Polity Press, Cambridge.

Ng, K.H., \& Kemp, R., 2020. Understanding and reducing the fear of COVID-19. J. Zhejiang Univ-Sci. B. https://doi.org/10.1631/jzus.B2000228

Páez, D., Echebarria, A., Valencia, J., Romo, I., Juan, C.S., Vergara, A., 1991. AIDS social representations; contents and processes. J. Community Appl. Soc. Psychol. 1, 89-104. https://doi.org/10.1002/casp.2450010204 
Pennycook, G., McPhetres, J., Zhang, Y., Lu, J. G., \& Rand, D. G., 2020. Fighting COVID19 misinformation on social media: experimental evidence for a scalable accuracy-nudge intervention. Psychol. Sci., 31(7), 770-780. https://doi.org/10.1177/0956797620939054

Pidgeon, N., Kasperson, R.E. \& Slovic, P., 2003. The social amplification of risk. Cambridge University Press. https://doi.org/10.1017/CBO9780511550461

Power, M., 2007. Organized uncertainty: Designing a world of risk management. Oxford University Press.

Rateau, P., 1995a. Dimensions descriptive, fonctionnelle et évaluative des représentations sociales - une étude exploratoire. Pap. Soc. Rep. 4, 1-14. http://psr.iscteiul.pt/index.php/PSR/article/view/205

Rateau, P., 1995b. Le noyau central des représentations sociales comme système hiérarchisé : une étude sur la représentation du groupe. Cah. Int. Psychol. Soc. 26, 29-52.

Rateau, P., Moliner, P., Guimelli, C., Abric, J.-C., 2011. Social Representation Theory, in: Van Lange, P.A.M., Kruglanski, A.W., Higgins, E.T. (Eds.), Handbook of Theories of Social Psychology. Sage, Thousand Oaks, CA, pp. 477-487.

Ribeiro, B., Hartley, S., Nerlich, B., Jaspal, R., 2018. Media coverage of the Zika crisis in Brazil: The construction of a 'war' frame that masked social and gender inequalities. Soc. Sci. Med. 200, 137-144. https://doi.org/10.1016/j.socscimed.2018.01.023

Robin, C., 2004. Fear. The History of a Political Idea. Oxford University Press, New York.

Rouquette, M.-L., 2009. La pensée sociale. Perspectives fondamentales et recherches appliquées. Erès, Toulouse.

Rouquette, M.-L., 2007. Une taxinomie des peurs collectives. Psicologia 21, 17-29.

Rouquette, M.-L., 1973. La pensée sociale, in: Moscovici, S. (Ed.), Introduction à La Psychologie Sociale (Tome 2). Larousse, Paris, pp. 298-327.

Salecl, R., 2004. On anxiety. Routledge, London \& New York. https://doi.org/10.4324/9780203508282

Schönbrodt, F.D., Perugini, M., 2013. At what sample size do correlations stabilize ? J. Res. Pers. 47, 609-612. https://doi.org/10.1016/j.jrp.2013.05.009

Slovic, P., 1987. Perception of Risk. Science (80-. ). 236, 280-285. https://doi.org/https://doi.org/10.1126/science.3563507 
Slovic, P., 2000. The perception of risk. Earthscan publication.

Stuber, M., 2003. Divine punishment or object of research? The resonance of earthquakes, floods, epidemics and famine in the correspondence network of Albrecht von Haller. Environ. Hist. Camb. 9, 173-193. https://doi.org/10.3197/096734003129342818

Tafani, É., Souchet, L., 2002. Commitment to pro-versus counter-attitudinal behavior and the dynamics of social representations. Swiss J. Psychol. 61, 34-44. https://doi.org/10.1024//1421-0185.61.1.34

Tavani, J.L., Piermattéo, A., Collange, J., Lo Monaco, G., 2014. Pour une prise en compte des représentations sociales dans l'étude de la santé au travail : des pistes pour la prévention. Arch. des Mal. Prof. l'Environnement 75, 478-491. https://doi.org/10.1016/j.admp.2014.04.005

Tudor, A., 2003. A (Macro) Sociology of Fear? Sociol. Rev. 51, 238-256. https://doi.org/10.1111/1467-954X.00417

Valdiserri, R.O., 1987. Epidemics in perspective. J. Med. Humanit. Bioeth. 8, 95-100. https://doi.org/10.1007/BF01119854

Vergès, P., 1992. L'évocation de l'argent: une méthode pour la définition du noyau central d'une représentation. Bull. Psychol. 45, 203-209.

Wachelke, J., 2012. Social Representations: A Review of Theory and Research from the Structural Approach. Univ. Psychol. 11, 729-741.

Washer, P., Joffe, H., 2006. The "hospital superbug": social representations of MRSA. Soc. Sci. Med. 63, 2141-52. https://doi.org/10.1016/j.socscimed.2006.05.018 
Table 1. The four original "reasons" for an object of fear

\begin{tabular}{llll}
\hline Human Intentional & A & Non-human Intentional & B \\
\hline Human Unintentional & C & Non-human Unintentional & D \\
\hline
\end{tabular}

Table 2. The different categories of associations with rank-frequency methods (as defined by Vergès, 1994)

\begin{tabular}{lll}
\hline Frequency & Appearance ranking \\
\cline { 2 - 3 } & Low & High \\
\hline High & Cell 1 - Core zone & Cell 2 - Potential change zone \\
Low & Cell 3 - Potential change zone & Cell 4 - Periphery \\
\hline
\end{tabular}

Table 3. The four zones of the representation of the total population $(N=1060)$. The frequency and the average rank of occurrence of each unit are in brackets.

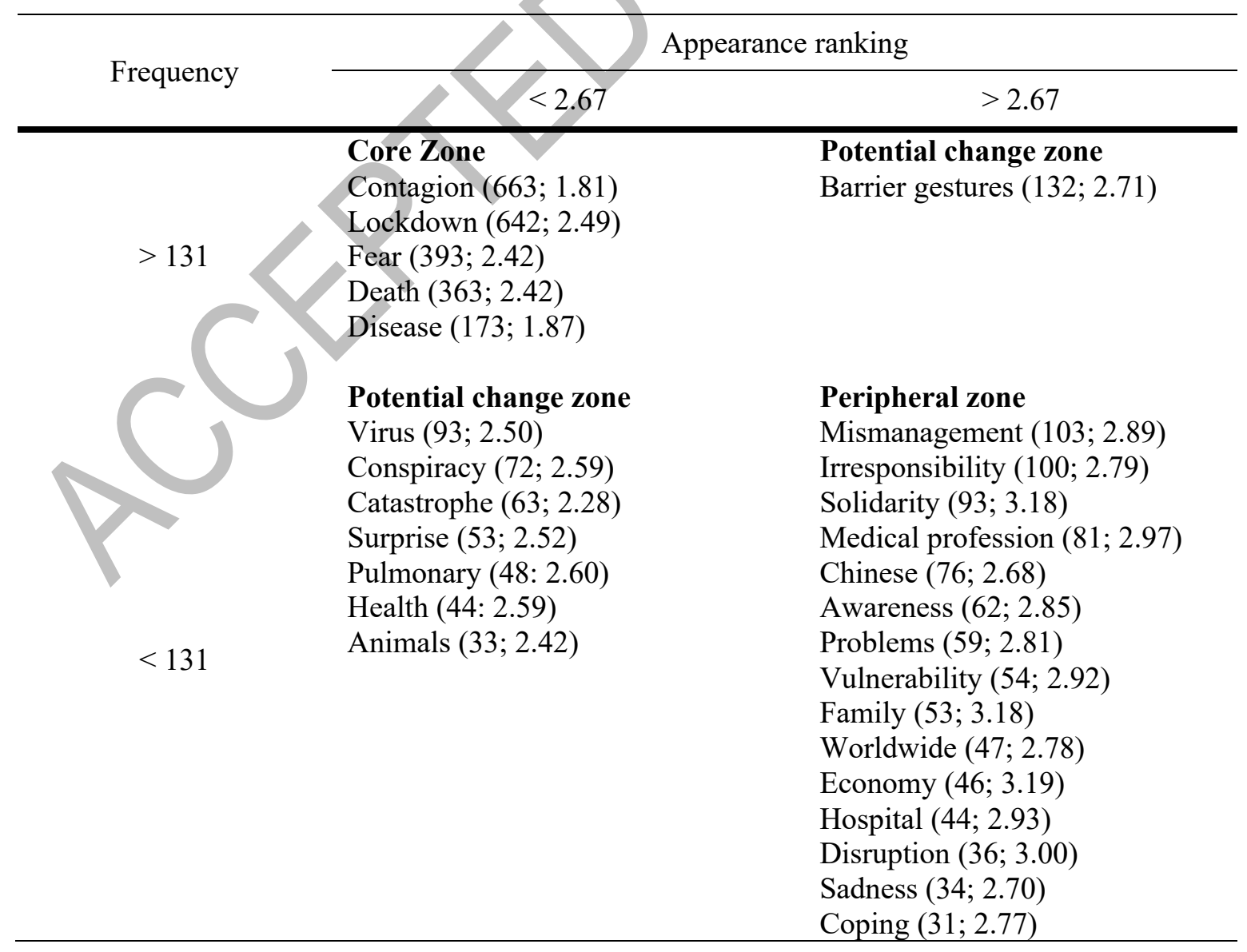


Table 4. The four zones of the representation of the Human Intentional condition $(N=84)$. The frequency and the average rank of occurrence of each unit are in brackets.

\begin{tabular}{cll}
\hline \multirow{2}{*}{ Frequency } & \multicolumn{1}{c}{ Appearance ranking } \\
\cline { 2 - 3 } & \multicolumn{1}{c}{$<2.65$} & \multicolumn{1}{c}{$>2.65$} \\
\hline \multirow{3}{*}{$>15$} & Core Zone & Potential change zone \\
& Contagion $(29 ; 2.06)$ & Mismanagement $(16 ; 2.75)$ \\
& Fear $(40 ; 2.40)$ & \\
& Lockdown $(37 ; 2.59)$ & \\
Conspiracy $(31 ; 2.38)$ & \\
& Potential change zone & \\
& Disease $(10 ; 2.10)$ & Peripheral zone \\
& Chinese $(9 ; 2.55)$ & Barrier gestures $(8 ; 2.87)$ \\
& Catastrophe $(5 ; 2.40)$ & Irresponsibility $(7 ; 3.14)$ \\
& & Virus $(6 ; 2.66)$ \\
& & Medical profession $(5 ; 2.80)$ \\
& & Sadness $(5 ; 2.80)$ \\
& & Worldwide $(5 ; 3.00)$ \\
& & Government $(5 ; 3.20)$ \\
& & Solidarity $(5 ; 3.20)$ \\
& &
\end{tabular}

Table 5. The four zones of the representation of the Human Unintentional condition $(N=112)$. The frequency and the average rank of occurrence of each unit are in brackets.

\begin{tabular}{lll}
\hline \multirow{2}{*}{ Frequency } & \multicolumn{1}{c}{ Appearance ranking } \\
\cline { 2 - 3 } & \multicolumn{1}{c}{$<2.54$} & \multicolumn{1}{c}{$>2.54$} \\
\hline & Core Zone & \multicolumn{1}{c}{ Potential change zone } \\
& Death $(60 ; 2.31)$ & Lockdown $(73 ; 2.59)$ \\
& Contagion $(60 ; 1.90)$ & Fear $(45 ; 2.62)$ \\
& Disease $(22 ; 1.95)$ & Barrier gestures $(22 ; 2.68)$ \\
& & \\
& Potential change zone & Peripheral zone \\
& Chinese $(13 ; 2.30)$ & Solidarity $(11 ; 3.00)$ \\
& Irresponsibility $(12 ; 2.33)$ & Medical profession $(9 ; 3.22)$ \\
& Mismanagement $(6 ; 2.33)$ & Economy $(8 ; 3.00)$ \\
& Conspiracy $(6 ; 2.33)$ & Virus $(7 ; 3.00)$ \\
& Catastrophe $(5 ; 2.40)$ & Family $(6 ; 2.83)$ \\
& Pulmonary $(5 ; 2.40)$ & Vulnerability $(5 ; 2.80)$ \\
& Government $(5 ; 2.50)$ & \\
\hline
\end{tabular}


Table 6. The four zones of the representation of the Non-Human Intentional condition $(\mathbf{N}=$ 133). The frequency and the average rank of occurrence of each unit are in brackets.

\begin{tabular}{cll}
\hline \multirow{2}{*}{ Frequency } & \multicolumn{2}{c}{ Appearance ranking } \\
\cline { 2 - 3 } & \multicolumn{1}{c}{$<2.54$} & \multicolumn{1}{c}{$>2.54$} \\
\hline \multirow{3}{*}{$>20$} & Core Zone & Potential change zone \\
& Death $(54 ; 2.35)$ & Fear $(47 ; 2.66)$ \\
& Contagion $(73 ; 1.93)$ & Solidarity $(38 ; 3.45)$ \\
& Lockdown $(81 ; 2.26)$ & \\
& Potential change zone & Peripheral zone \\
& Awareness $(18 ; 2.61)$ & Problems $(22 ; 3.66)$ \\
& Virus $(17 ; 2.12)$ & Medical profession $(16 ; 2.93)$ \\
& Disease $(16 ; 1.62)$ & Mismanagement $(14 ; 2.92)$ \\
& Barrier gestures $(13 ; 2.38)$ & Irresponsibility $(12 ; 3.00)$ \\
& & Conspiracy $(10 ; 3.00)$ \\
\hline
\end{tabular}

Table 7. The four zones of the representation of Non-Human Unintentional condition $(N=731)$. The frequency and the average rank of occurrence of each unit are in brackets.

\begin{tabular}{lll}
\hline \multirow{2}{*}{ Frequency } & \multicolumn{1}{c}{ Appearance ranking } \\
\cline { 2 - 3 } & \multicolumn{1}{c}{ Core Zone } & \multicolumn{1}{c}{$>2.68$} \\
\hline \multirow{4}{*}{$>109$} & Death $(207 ; 2.50)$ & Potential change zone \\
& Contagion $(502 ; 1.77)$ & \\
& Lockdown $(451 ; 2.50)$ & \\
Fear $(262 ; 2.35)$ & \\
& Disease $(126 ; 1.88)$ & \\
& Potential change zone & Peripheral zone \\
& Virus $(73 ; 2.48)$ & Barrier gestures $(90 ; 2.75)$ \\
& Catastrophe $(49 ; 2.30)$ & Irresponsibility $(69 ; 2.79)$ \\
Surprise $(41 ; 2.58)$ & Solidarity $(68 ; 3.17)$ \\
& Health $(44 ; 2.59)$ & Mismanagement $(67 ; 2.98)$ \\
& & Medical profession $(51 ; 2.96)$ \\
& & Chinese $(46 ; 2.80)$ \\
& & Problems $(43 ; 3.16)$ \\
& & Family $(42 ; 3.16)$ \\
& & Vulnerability $(40 ; 3.05)$ \\
& & Awareness $(39 ; 3.05)$ \\
& & Hospital $(36 ; 2.80)$ \\
& & Worldwide $(33 ; 2.84)$ \\
& & Pulmonary $(32 ; 2.75)$ \\
\hline
\end{tabular}


Table 8. Descriptive statistics of the core zone valence of each sample

\begin{tabular}{llllll}
\hline & $\mathrm{M}$ & $\mathrm{SD}$ & $\mathrm{N}$ & $\mathrm{Min}$. & Max. \\
\hline Human Intentional & -1.67 & 2.02 & 178 & -3.00 & 3.00 \\
Non-Human Intentional & -1.34 & 1.86 & 208 & -3.00 & 3.00 \\
Human Non-Intentional & -2.13 & 1.43 & 143 & -3.00 & 3.00 \\
Non-Human Non-Intentional & -1.61 & 1.65 & 1543 & -3.00 & 3.00 \\
\hline
\end{tabular}

Figure 1. Interaction plot for the prototypicality index

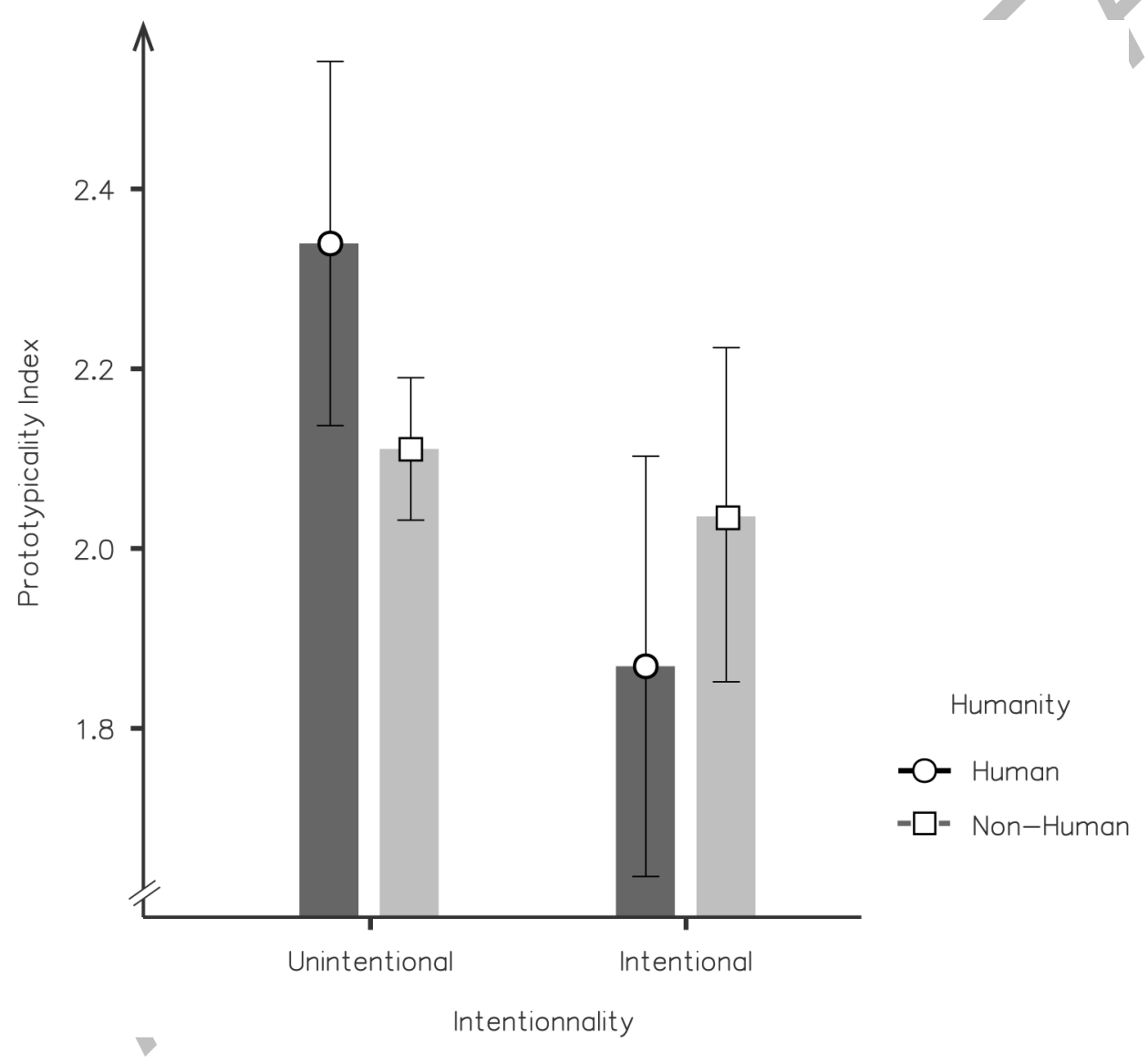

